\title{
Prevalence of and Factors Associated with Depression and Anxiety in Brazilian Medical Students
}

\author{
Prevalência de Fatores Associados à Depressão e Ansiedade em \\ Estudantes de Medicina Brasileiros
}

\author{
Christiane Fernandes Ribeiro ${ }^{\mathrm{I}}$ (iD) \\ Carolina Martins Cabrita Lemos ${ }^{\mathrm{II}} \mathrm{D}$ \\ Nina Nogueira Alt ${ }^{\mathrm{II}}$ (ID \\ Rulliany Lizia Tinoco Marins ${ }^{\mathrm{II}}$ (ID) \\ Weydler Campos Hottz Corbiceiro ${ }^{\text {II }}$ (D) \\ Maria Isabel do Nascimento ${ }^{\mathrm{I}}$ (iD
}

\section{KEY-WORDS}

- Depression.

- Anxiety.

- Medical Students.

- Prevalence.

- Risk Factors.
${ }^{\mathrm{I} U n i v e r s i d a d e ~ F e d e r a l ~ F l u m i n e n s e, ~ N i t e r o ́ i, ~ R i o ~ d e ~ J a n e i r o, ~ B r a z i l . ~}$

${ }^{\mathrm{II}}$ Hospital Universitário Antônio Pedro, Niterói, Rio de Janeiro, Brazil.

Introduction: Although mental health is an essential condition for the human development, the scientific literature shows a high frequency of depression and anxiety in university students, mainly among medical students. To contribute to a better understanding concerning medical students' mental health, this study had the following objectives: (a) to estimate the prevalence of indicative scores for anxiety, depression, and for simultaneous anxiety and depression, and (b) to analyze factors associated with these conditions in medical students at a federal university in Brazil. Methods: This is a cross-sectional study including students from a federal medical school in the state of Rio de Janeiro. Participants were enrolled during the first semester of 2015. Mental disorders were assessed with Hospital Anxiety and Depression Scale (HADS). The magnitude of mental disorders and its associated factors were analyzed calculating prevalence rates and unadjusted and adjusted prevalence ratios (PR) and 95\% confidence intervals (95\% CI). Results: We analyzed 355 students. Anxiety was the most common condition (41.4\%), followed by depression (8.2\%), and both anxiety and depression simultaneously (7.0\%). After adjustment of multivariate models and considering both gender and age as confounding variables, our results showed a differentiated risk pattern in relation to three outcomes analyzed. Anxiety risk increased with 'feeling alone' (adjusted PR: 1.59; 95\% CI: 1.123; 2.259), 'having a history of psychological and/or psychiatric treatment before entering university' (adjusted PR: 1.63; 95\% CI: 1.052; 2.542), and 'feeling morally harmed at college' (adjusted PR: 1.66; (95\% CI: 1.168; 2.364). Depression risk increased with 'feeling alone' (adjusted PR: 6.84; 95\% CI: 2.047; 22.894) and 'having a history of psychological and/ or psychiatric treatment before entering university' (adjusted PR: 4.74; 95\% CI: 1.790; 12.579). Simultaneous anxiety and depression were associated with 'feeling alone' (adjusted PR: 8.90; 95\%CI: 2.075; 38.208) and 'having a history of psychological and/or psychiatric treatment during the medical course (adjusted PR: 3.16; 95\% CI: 1.061; 9.439) and before (adjusted PR: 6.01; 95\% CI: 2.000; 18.098) entering university'. Conclusion: Anxiety and depression are common conditions in medical students. The main associated factors were therapies for mental health before entering in university, loneliness and lack of respect in interpersonal relationships during the medical course. Therefore, initiatives aiming at better welcoming students and reducing conflicting situations can help minimizing these mental problems during university career, once they have a large impact not only in their quality of life, but also in the way they will deal with their patients in the future. 


\section{PALAVRAS-CHAVE}

- Depressão.

- Ansiedade.

- Estudantes de Medicina.

- Prevalência.

- Fatores de Risco.

\section{RESUMO}

Introdução: Embora a saúde mental seja uma condição essencial para o desenvolvimento humano, a literatura científica mostra alta frequência de depressão e ansiedade em universitários, principalmente entre estudantes de Medicina. Para contribuir para um melhor entendimento sobre a saúde mental de estudantes de Medicina, esta pesquisa teve os seguintes objetivos: 1. estimar a prevalência de escores indicativos de ansiedade, depressão e ansiedade e depressão simultâneas, e 2. analisar os fatores associados com tais condições em estudantes de Medicina de uma universidade federal do Brasil. Métodos: Trata-se de um estudo do tipo transversal realizado com 355 estudantes de uma faculdade de medicina do Rio de Janeiro. Os participantes foram recrutados durante o primeiro semestre do ano de 2015. As desordens mentais foram avaliadas com o uso da Hospital Anxiety and Depression Scale (Hads). A magnitude dos transtornos mentais e os fatores associados foram analisados com a obtenção de estimativas de prevalência $e$ de razão de prevalência (RP) não ajustada e ajustada e de intervalos de confiança de 95\% (IC 95\%). Resultados: Analisaram-se 355 estudantes. Ansiedade foi a condição mais comum (41,4\%), seguida de depressão (8,2\%) e de depressão e ansiedade simultâneas (7,0\%). Depois do ajustamento dos modelos multivariados e considerando tanto gênero quanto idade como variáveis de confusão, nossos resultados mostraram um padrão de risco diferenciado em relação aos três desfechos analisados. O risco de ansiedade aumentou com o fato de se "sentir sozinho" (RP ajustada: 1,59; IC 95\%: 1.123; 2,259), "ter histórico de acompanhamento psiquiátrico/psicológico antes de ingressar na universidade" (RP ajustada: 1,63; IC 95\%: 1,052; 2,542) e "se sentir moralmente lesado na faculdade" (RP ajustada: 1,66; IC 95\%: 1,168; 2,364). O risco de depressão aumentou com se "sentir sozinho" (RP ajustada: 6,84; IC 95\%: 2,047; 22,894) e "ter histórico de acompanhamento psiquiátrico/psicológico antes de ingressar na universidade" (RP ajustada: 4,74; IC 95\%: 1,790; 12,579). Ansiedade e depressão simultâneas foram associadas com se "sentir sozinho" (RP ajustada: 8,90; IC 95\%: 2,075; 38,208) e "ter histórico de acompanhamento psiquiátrico/psicológico durante (RP ajustada: 3,16; IC 95\%: 1,061; 9,439) e antes (RP ajustada: 6,01; IC 95\%: 2,000; 18,098) de ingressar na universidade". Conclusão: Ansiedade e depressão são comuns em estudantes de Medicina. Os principais fatores associados foram tratamentos para desordens mentais antes do ingresso na universidade, solidão e relações interpessoais problemáticas durante a graduação. Dessa maneira, um melhor acolhimento e uma redução de situações conflituosas podem ajudar a minimizar essas condições frequentes em escolas médicas, uma vez que impactam não apenas a própria qualidade de vida, como também a forma de lidar com os seus pacientes no futuro.

Received on 10/02/19

Accepted on 11/09/19

\section{INTRODUCTION}

Mental health preservation is an essential condition for university students, independently of their chosen career ${ }^{1}$. However, medical students constitute a target group, as they are subject to lower psychological and social well-being when compared to other people of same age ${ }^{2}$. Studies on the matter become even more relevant as they involve future physicians who will care for the health of others, besides health benefits for the professionals themselves. Some authors have shown that physicians with depressive disorders have a higher propensity to committing errors in their professional practice ${ }^{3,4}$.

According to the World Health Organization (WHO) ${ }^{5}$, depression is a condition characterized by symptoms of prolonged sadness, inability to take pleasure in former interests, feelings of guilt, worthlessness, significant changes in appetite and sleep patterns, loss of energy, and/or inability to concentrate, among others. Depression may shown continuous progression or be recurring and, in some cases be so severe as to lead to suicide. The $\mathrm{WHO}^{5}$ also defines anxiety disorders as conditions related to feelings of anguish and fear, including generalized anxiety disorder, panic syndrome, phobias, obsessive-compulsive disorder, and post-traumatic stress.
Although the topic of mental health among medical students has been covered by important publications in the literature, both national ${ }^{6}$ and international ${ }^{7,8}$, most of these publications focus on prevalence estimates. Therefore, there is a lack of consistent information regarding factors related to these problems.

Utilizing an instrument (Hospital Anxiety and Depression Scale - HADS) with a good performance history when used in the general population ${ }^{9}$, the present study aimed to contribute to a better understanding of medical students' mental health, broadening the analysis to the predisposing factors. Hence, the objectives were (a) to estimate the prevalence of indicative scores for anxiety, depression, and for simultaneous anxiety and depression, and (b) to analyze factors associated with these conditions in medical students at a federal university in Brazil.

\section{METHODS}

This study was developed at the medical school of a federal university in Rio de Janeiro, Brazil. In this institution, the medical training is based on a theoretical-demonstrative and a practical-conceptual program of progressive complexity, lasting four years, and followed by two years of medical internship. The workload comprises 9,135 hours.

REVISTA BRASILEIRA DE EDUCAÇÃO MÉDICA

2 44 (1) : e021; 2020 


\section{Participants}

Candidates to the study were students enrolled in the medical program $(\mathrm{n}=924)$ who, at the time of data collection, were regularly attending classes and/or active in the medical internship program. Students involved in the research project or who were part of the data collecting team were excluded from the study $(n=4)$.

\section{Study Sample}

The study sample was calculated considering two objectives separately. Firstly, to obtain prevalence rates in the whole student group, we considered anxiety prevalence of $15 \%$, an error of up to ten percentage points, and $95 \%$ confidence interval $(95 \% \mathrm{CI})$. Secondly, to compare the two groups (one with and the other without the outcome) and to get prevalence ratios, we considered the same prevalence rate (15\%), study power of $80 \%$, risk of 2.0 and alpha error of $5 \%$ (95\% confidence interval - 95\% CI). The minimum sample size was estimated at 162 and 266 students, respectively. After a convenient selection of participants, the study population consisted of 355 students: 218 females, 134 males, and 3 who did not identify their gender.

\section{Design and Data Collection}

Data collection was carried out in the classrooms, over the first semester of 2015, from March until June. Students who were not present or who chose to respond at a later time used the online version via Google Forms. Socio-demographic characteristics and structured and semi-structured questions of interest to the study were answered by the participants themselves.

\section{Study Variables}

Dependent variables were individually analyzed, considering indicative scores of: Anxiety (yes/no); Depression (yes/no); and Anxiety and Depression simultaneously (yes/no). This classification was obtained through the administration of the Hospital Anxiety and Depression Scale (HADS). This instrument was developed by Zigmond and Snaith ${ }^{10}$ and has a long usage history. The first validation studies ${ }^{11,12}$ in Brazil were implemented in the 1990s. The tool consists of 14 items, seven of which are used to assess depression and seven to assess anxiety. The items for assessing anxiety cover the following questions: (i) to feel tensed or "wound up"; (ii) to feel interested in things as one used to; (iii) to feel something awful is about to happen; (iv) to laugh readily and see the funny side of things; (v) to worry a lot; (vi) to feel cheerful; (vii) to sit at ease and feel relaxed. The items for assessing depression include the following questions: (i) to feel slowed down; (ii) to get a frightened feeling like butterflies in the stomach; (iii) to lose interest in one's appearance; (iv) to feel restless; (v) to feel optimistic about the future; (vi) to have panic attacks; (vii) to enjoy a good book or radio or TV program.

\section{Anxiety and Depression Scoring}

Points for items in each HADS subscale are based on a Likert scale, with a variation from zero to three, and sum of zero to twenty-one. HADS allows individuals' classification as: without depression and/or anxiety ( $\leq 7$ ), borderline for depression and/or anxiety (8 to 10 ), and with depression and/or anxiety $(\geq 11)$. Students in which the sum of points in the scale $(\geq 11)$ indicated the problem (Anxiety, Depression, or Anxiety and Depression) were classified as 'yes.' Bordering or negative situations were classified as 'no.' Here, we have also classified the students with both conditions concurrently, verifying whether the sum of points for depression and for anxiety reached $\geq 11$. Otherwise, the concurrence of both situations was considered as being absent.

\section{Independent variables}

Independent variables were: gender (female or male), age (18 to 21 years; 22 to 27 years; 28 or older), medical course stage (basic, clinical, or medical internship), feeling alone (yes/no), having a history of psychological and/or psychiatric treatment (never, started during the course, started before the course), person(s) the student was living with (family, friends, alone), family history of anxiety and/or depression (no case, anxiety case, depression case, or both), and feeling morally harmed at the college (yes/no). In case of a positive answer to the last question, another question was addressed to clarify the causative agent (student, professor, or both).

\section{Data Analysis}

The prevalence of depression and anxiety as well as $95 \%$ confidence intervals were calculated. As depression and anxiety appeared frequently, Poisson regression with robust variance estimator was employed to estimate the prevalence ratio - PR - (unadjusted and adjusted), and $95 \%$ confidence intervals (CI). That way, we avoided overestimation of effects between dependent and independent variables.

\section{Ethical Aspects}

This study follows the recommendations for research in humans, as stated in Resolution Number 466 of 12 December 2012, and was approved by the Research Ethics Committee of our institution (Finding \#912.412, dated 06 November 2014). All participants were invited, properly informed about, and included in the study only after signing an informed consent form.

\section{RESULTS}

Potential participants were 373 students attending classes or doing medical internship activities. Eighteen students (12 women and 6 men) refused to participate or did not answer the questionnaire. All of them were doing medical internship activities. The non-response rate was of $4.8 \%$. Thus, 355 students were analyzed, with a higher proportion of female students (61.93\% versus $38.07 \%$ ) compared with male students. Mean age was 23.06 years (standard deviation 3.10 years). There was no significant difference in mean age between males (22.87 years) and females (23.18 years).

The use of HADS showed students had anxiety (41.4\%; 95\% CI: $36.3 \%$; 46.6\%), depression (8.2\%; 95\% CI: 5.3\%; 11.0\%) and both depression and anxiety (7.0\%; 95\% CI: 4.4\%; 9.7\%).

With the exception of the gender variable (female), which showed a statistically significant difference only for 'anxiety', a pattern of risk factors with $\mathrm{p}$-values $<0.05$ (feeling alone, having a history of psychiatric/ psychological treatment, and feeling morally harmed) was identified for all three analyzed outcomes. The students' characteristics according to mental health status are summarized in Table 1.

In the bivariate analysis, while the category 'female gender' increased the risk in more than $50 \%$ just for anxiety when compared to 'male gender,' the category 'age $=28$ years or more' increased in 2.5 times the risk just for depression compared to the 18-21 year range. The risk pattern for 'feeling

REVISTA BRASILEIRA DE EDUCAÇ̃̃o MÉDICA

3 44 (1) : e021; 2020 
alone, 'having a history of psychiatric/psychological treatment,' and 'feeling morally harmed' was maintained for all three analyzed outcomes (Table 2).

Having a 'history of psychiatric/psychological treatment before entering the university', 'loneliness', and 'feeling morally harmed at the college' were the main factors associated with mental disorders, after adjustment of multivariate models, adjusted for gender and age (Table 3).

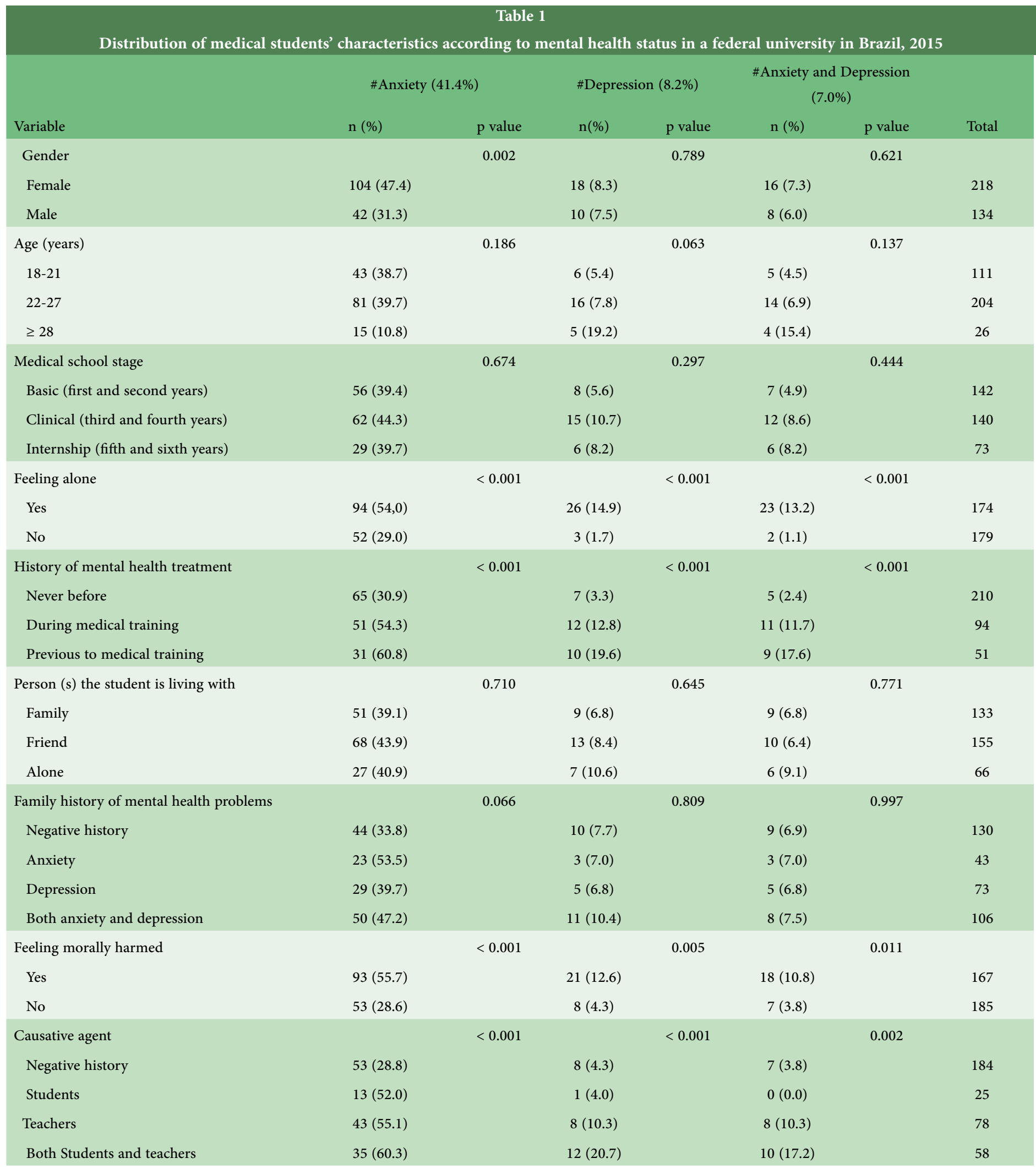

\#Zigmond and Snaith [10]. The hospital anxiety and depression scale. Acta Psychiatr Scand 1983; 67(6):361-70. Available for textual search at https://onlinelibrary.wiley.com/doi/ pdf/10.1111/j.1600-0447.1983.tb09716.x 
Bivariate analysis: unadjusted prevalence ratio of factors associated with anxiety, depression, both anxiety and depression in medical students from a federal university in Brazil, 2015.

$$
\text { \#Anxiety \#Depression }
$$

\section{\#Depression}

Unadjusted $\mathrm{PR}^{*}$

and $95 \% \mathrm{CI}^{* *}$

$1.52(1.063 ; 2.177)$

ref***

Male

Age (years)

18-21

22-27

$\geq 28$

Medical school stage

Basic (first and second years)

$\operatorname{ref}^{* * *}$

Clinical (third and fourth years)

Internship (fifth and sixth years)

Feeling alone

Yes

No

$1.85(1.325 ; 2.609)$

ref $^{* * *}$

$\operatorname{ref}^{* * *}$

$1.75(1.214 ; 2.529)$

$1.96(1.280 ; 3.012)$

$\operatorname{ref}^{* * *}$

$1.12(0.782 ; 1.610)$

$1.04(0.657 ; 1.665)$

$\operatorname{ref}^{* * *}$

$1.58(0.954 ; 2.616)$

$1.17(0.734 ; 1.875)$

$1.39(0.929 ; 2.089)$

$1.94(1.387 ; 2.723)$

History of mental health treatmen

$\operatorname{ref}^{* * *}$

$1.90(0.806 ; 4.485)$

$1.45(0.506 ; 4.204)$

$8.91(2.698 ; 29.456)$

$\operatorname{ref}^{* * *}$

$\operatorname{ref}^{* * *}$

$3.82(1.507 ; 9.727)$

$5.88(2.239 ; 15.453)$

Person (s) the student is living with
Friends

Alone
Negative history

Anxiety

Depression

Both anxiety and depression

Yes

No
Feeling morally harmed

$$
\text { ref }^{* * *}
$$

Unadjusted $\mathrm{PR}^{\star}$

and $95 \% \mathrm{CI}^{\star \star}$

$1.10(0.510 ; 2.396)$

ref $^{* * *}$

$\operatorname{ref}^{* * *}$

$1.45(0.567 ; 3.708)$

$1.52(0.548 ; 4.229)$

$3.55(1.085 ; 11.657)$

$3.41(0.917 ; 12.718)$

Unadjusted $\mathrm{PR}^{\star}$

and $95 \% \mathrm{CI}^{* *}$

$1.22(0.526 ; 2.872)$

ref $^{* * *}$

$\operatorname{ref}^{* * *}$

$1.73(0.684 ; 4.416)$

$1.66(0.560 ; 4.961)$

$11.83(2.789 ; 50.178)$

$\operatorname{ref}^{* * *}$

$\operatorname{ref}^{* * *}$

4.91 (1.707; 14.145)

$7.41(2.483 ; 22.115)$

ref $^{* * *}$

$1.23(0.529 ; 2.899)$

$1.56(0.583 ; 4.208)$

$0.95(0.387 ; 2.346)$

$1.34(0.478 ; 3.774)$

$\operatorname{ref}^{* * *}$

$0.90(0.249 ; 3.295)$

$1.00(0.272 ; 3.722)$

$0.89(0.304 ; 2.605)$

$0.98(0.331 ; 2.952)$

$1.34(0.572 ; 3.176)$

$1.09(0.420 ; 2.825)$

$2.84(1.189 ; 6.820)$

$\operatorname{ref}^{* * *}$

${ }^{\star}$ Unadjusted prevalence ratio; ${ }^{* *} 95 \%$ confidence intervals; ${ }^{\star * *}$ ref (reference: unexposed or lower exposed category);

\#Zigmond and Snaith [10]. The hospital anxiety and depression scale. Acta Psychiatr Scand 1983; 67(6):361-70. Available for textual search at https://onlinelibrary.wiley.com/doi/pdf/10.1111/j.1600-0447.1983. tb09716.x 


\begin{tabular}{|c|c|c|c|}
\hline \multicolumn{4}{|c|}{$\begin{array}{r}\text { Table } 3 \\
\text { Multivariate analysis: adjusted prevalence ratio of factors associated with anx } \\
\text { from a federal university in Brazil }\end{array}$} \\
\hline \multirow[b]{2}{*}{ Variable } & Final Model of \#Anxiety & \multirow{2}{*}{$\begin{array}{l}\text { Final Model of \#Depression } \\
\text { Adjusted } \mathrm{PR}^{\star} \text { and } \\
95 \% \mathrm{CI}^{* *}\end{array}$} & \multirow{2}{*}{$\begin{array}{c}\text { Final Model of } \\
\text { \#Depression and Anxiety } \\
\text { Adjusted } \mathrm{PR}^{*} \text { and } \\
\text { 95\% } \mathrm{Cl}^{* *}\end{array}$} \\
\hline & $\begin{array}{c}\text { Adjusted } \mathrm{PR}^{*} \text { and } \\
95 \% \mathrm{CI}^{* *}\end{array}$ & & \\
\hline \multicolumn{4}{|l|}{ Gender } \\
\hline Female & $1.32(0.925 ; 1.907)$ & $0.91(0.421 ; 2.005)$ & $1.01(0.429 ; 2.393)$ \\
\hline Male & $\operatorname{ref}^{* * *}$ & $\operatorname{ref}^{* * *}$ & $\operatorname{ref}^{* * *}$ \\
\hline \multicolumn{4}{|l|}{ Feeling alone } \\
\hline Yes & $1.59(1.123 ; 2.259)$ & $6.84(2.047 ; 22.894)$ & $8.90(2.075 ; 38.208)$ \\
\hline No & $\operatorname{ref}^{* * *}$ & $\operatorname{ref}^{* * *}$ & $\operatorname{ref}^{* * *}$ \\
\hline \multicolumn{4}{|c|}{ History of mental health treatment } \\
\hline Never before & $\operatorname{ref}^{* * *}$ & $\operatorname{ref}^{* * *}$ & $\operatorname{ref}^{* * *}$ \\
\hline During medical training & $1.42(0.980 ; 2.081)$ & $2.51(0.957 ; 6.612)$ & $3.16(1.061 ; 9.439)$ \\
\hline Prior to medical training & $1.63(1.052 ; 2.542)$ & $4.74(1.790 ; 12.579)$ & $6.01(2.000 ; 18.098)$ \\
\hline \multicolumn{4}{|l|}{ Feeling morally harmed } \\
\hline Yes & $1.66(1.168 ; 2.364)$ & $2.02(0.842 ; 4.842)$ & $1.92(0.748 ; 4.929)$ \\
\hline No & $\operatorname{ref}^{* * *}$ & $\operatorname{ref}^{* * *}$ & $\operatorname{ref}^{* * *}$ \\
\hline
\end{tabular}

${ }^{\star}$ Adjusted prevalence ratios; ${ }^{* *} 95 \%$ confidence intervals; ${ }^{* * *}$ ref (reference: unexposed or lower exposed category);

\# Zigmond and Snaith [10]. The hospital anxiety and depression scale. Acta Psychiatr Scand 1983; 67(6):361-70. Available for textual search at https://onlinelibrary.wiley.com/doi/ pdf/10.1111/j.1600-0447.1983.tb09716.x

\section{DISCUSSION}

The present study evaluated scores indicative of depression, anxiety, and both conditions present simultaneously in medical students and investigated the associated factors. Anxiety was the most common issue $(41.4 \%)$, with a frequency rate five times higher than depression (8.2\%), and almost six times higher than depression and anxiety together (7.0\%). 'Loneliness' and 'having a history of psychiatri c/psychological treatment before entering college' were the main factors associated with the three analyzed scores. 'Feeling morally harmed' during the course was associated exclusively with anxiety and emerges as a delicate question involving interpersonal relationships among students, as well as between students and teachers.

In the literature, there have been few studies delineating a risk profile for mental disorders in medical students, particularly in Brazilian universities. Our findings demonstrate that part of the problem precedes the students' academic career, and another part takes place during medical training. In Malaysia ${ }^{13}$, a median academic performance at high school level was associated with depression in candidates that entered medical school, with an impact on the learning process. The authors called attention to the fact that the problem chronically persists throughout medical training. In The United Kingdom, students with great difficulty in keeping up with academic activities due to mental health issues had a history of some disorder that preceded admission to medical school, with a probability ratio of 5.03 (95\% CI: $1.32 ; 19.19)^{14}$. In Brazil, a study developed at a federal university in the northern region of the country showed that psychological or psychiatric treatment had no effect on depression ${ }^{15}$. It is possible that the lack of association was due to the fact that the authors analyzed mild, moderate, and severe depression levels jointly.

Although the effect of 'feeling alone' was relevant, it is worth pointing out that it is a problem that can be a risk factor ${ }^{16}$ for, but also a consequence of mental disorders ${ }^{17}$. The interpretation of associations with possible reverse causality requires caution. Nonetheless, in Somalia ${ }^{1}$, a study with university students from nine different courses demonstrated that the absence of a close friend and the dissatisfaction with relationships with friends and family constituted important risk factors for mental health issues. In Brazil, it is common for the students to leave behind home and family and move to places that are foreign to them, in order to proceed with their studies. Minimizing the effects of this separation is not always possible by simply establishing new relationships. Hence, studies designed specifically to expand on the knowledge regarding the reason given for feeling lonely will help to understand its role on the mental health of medical students.

Mental disorders, including depression and anxiety, are global problems which cause disability and death in most of the world. Around 800,000 deaths by suicide each year are related to depressive disorders. Estimates for the year 2015 demonstrated that 322 million people were living with depression and more than 264 million with anxiety, corresponding to a global prevalence of $4.4 \%$ and $3.6 \%$, respectively. In the Americas, Brazil has the second highest prevalence (5.8\%) of people with depression, behind only the United States (5.9\%). Brazil is at the top 
of the list of people living with anxiety, and it is estimated that $9.3 \%$ of the population is living with this mental disorder ${ }^{5}$.

Comparatively to the general Brazilian population, there seems to be no differences between our estimates for depression and those provided by the Pesquisa Nacional de Saúde-2013 ('National Health Research', or PNS-2013). According to Stopa et $\mathrm{al}^{18}, 7.6 \%$ (95\% CI: 7.2\%; 8.1\%) people aged $\geq 18$ years old have a self-reported diagnosis of depression. These authors demonstrated that among Brazilians with complete high school or incomplete higher education level, the frequency was $6.4 \%$ (95\% CI: $5.8 \%-7.0 \%$ ), and in those with complete higher education level, it was 8.7\% (95\% CI: 7.5\%; 9.9\%).

We measured the frequency of anxiety and depression using the 'Hospital Anxiety and Depression Scale' (HADS). Aiming at assessing exclusively potentially severe cases, we utilized the most restrictive cutoff point $(\geq 11)$ of the subscales. That way, our parameters did not differ from those of aggregate prevalence for depression classified as severe $(9.9 \%$; $95 \%$ CI: $6.5 \% ; 14.1 \%)$ and for anxiety $(31.5 \%$; $95 \%$ CI: $26.1 \% ; 37.1 \%)$ as shown by meta-analysis ${ }^{6}$ of Brazilian studies carried out with different tools. The overlapping of confidence intervals suggests that mental disorders in our students are similar to those found in students in other Brazilian institutions.

Different cutoff points for screening and classifying the severity of these mental problems deserve careful attention in prevalence studies and can partially explain the variability of estimates found using HADS and other tools. HADS has a long history of international use'; however, it has not been largely employed in Brazil yet. In the present scenario of growing academic interest in medical students' mental health, it was surprising that only one study ${ }^{19}$ was found in the consulted literature whose authors choose HADS. The study was conducted at a private school in Brazil and determined a prevalence rate of anxiety (19.7\%) and depression (5.6\%) using the restrictive cutoff point ( $\geq 11)$. After the $95 \%$ confidence intervals (95\% CI) estimate for anxiety (95\% CI: $14.6 \% ; 24.8 \%$ ) and for depression (95\% CI: $2.65 \%$; $8.54 \%$ ) based on sample parameters provided by Vasconcelos et $\mathrm{al}^{19}$, we observed that the frequency of anxiety is higher in our students, but the depression problem is similar to that observed in the private school.

International studies that used the cutoff point for severe disorder ( $\geq 11$ ), prevalence of anxiety and depression detected in a sample of 409 medical students in Pakistan were, respectively, $37 \%$ and $8.6 \%{ }^{20}$. Another study carried out with 450 medical students in Saudi Arabia estimated an anxiety prevalence rate of $34.9 \%$ and depression of $14.7 \%$, considering the same criterion of a cutoff point $\geq 11^{21}$. However, the mental status of medical students at Cambridge University (in The United Kingdom) seems to be less severe, since upon use of a cutoff point $\geq 8$ in HADS, which included borderline or false-positive cases, the higher prevalence (depression) was $10.6 \%$ during the third year, followed by $8.2 \%$ during the sixth year of the course ${ }^{22}$.

As limitations, we recognize that the cross-sectional design with data collection at a single point in time is not appropriate form to reach robust conclusions regarding outcome predictors. Nonetheless, the most important factor identified -psychiatric/psychological treatment- points to the severity of students' mental health situation prior to entering medical school. This reinforces the idea that, in order to mitigate these problems, measures should also consider the period prior to admission at the university.
Secondly, our results derive from the assessment of participants in classrooms or engaging in internship activities. This decision may have excluded people who were probably not fulfilling the programed activities and who may have been mentally frail. A similar result may be present among the eighteen students who refused to answer the questionnaire. In this case, our results may be underestimated, despite their similarity with other national and international studies.

Another limitation is the lack of information about hazing. Although this practice seems not to be common in our institution it is possible that some students had experienced some form of abuse with mental health repercussions. It is important to emphasize that according to Lima et $\mathrm{al}^{23}$ violence seems to be naturally embedded in acts that are not always seen as abusive by the academic community, some teachers included. Hazing is a problem that must be faced with seriousness and abolished from our educational institutions.

In conclusion, anxiety and depression are common in medical students. Specific treatments for these disorders prior to entering the university are the most important associated factors, followed by loneliness and lack of respect in interpersonal relationships at the university. Mental health in students in general should be part of the agenda for Education and Health in Brazil. This study suggests that solution propositions should consider the period preceding university admission, as well as initiatives regarding a better welcoming of students and reducing situations that may represent conflicts during the university career.

\section{REFERENCES}

1. Hersi L, Tesfay K, Gesesew H, Krahl W, Ereg D, Tesfaye M. Mental distress and associated factors among undergraduate students at the university of Hargeisa, Somaliland: a cross-sectional study. Int J Ment Health Syst 2017; 11(39).

2. Pagnin D, de Queiroz V. Comparison of quality of life between medical students and young general populations. Educ Health (Abingdon) 2015; 28(3): 209-12.

3. West CP, Huschka MM, Novotny PJ, Sloan JA, Kolars JC, Habermann TM et al. Association of perceived medical errors with resident distress and empathy: a prospective longitudinal study. JAMA 2006; 296(9): 1071-8.

4. West CP, Tan AD, Habermann TM, Sloan JA, Shanafelt TD. Association of resident fatigue and distress with perceived medical errors. JAMA 2009; 302(12): 1294-300.

5. World Health Organization. Depression and other common mental disorders: global health estimates. Geneva: World Health Organization; 2017. License: CC BY-NC-SA 3.0 IGO.

6. Pacheco JP, Giacomin HT, Tam WW, Ribeiro TB, Arab C, Bezerra IM et al. Mental Health problems among medical students in Brazil: a systematic review and meta-analysis. Rev Bras Psiquiatr 2017; 39(4): 369-378.

7. Puthran R, Zhang MW, Tam WW, Ho RC. Prevalence of depression amongst medical students: a meta-analysis. Med Educ 2016; 50(4): 456-68.

8. Rotenstein LS, Ramos MA, Torre M, Segal JB, Peluso MJ, Guille C et al. Prevalence of depression, depressive symptoms, and suicidal ideation among medical students: a systematic review and metaanalysis. JAMA 2016; 316(21): 2214-2236.

REVISTA BRASILEIRA DE EDUCAÇÃO MÉDICA

7 44 (1) : e021; 2020 
9. Bjelland I, Dahal AA, Haug TT, Neckelmann D. The validity of the Hospital Anxiety and Depression Scale. An updated literature review. J Psychosom Res 2002; 52(2): 69-77.

10. Zigmond AS, Snaith RP. The hospital anxiety and depression scale. Acta Psychiatr Scand 1983; 67(6): 361-70

11. Botega NJ, Bio MR, Zomignani MA, Garcia Jr C, Pereira WAB. Mood disorders among medical in-patients: a validation study of the hospital anxiety and depression scale (HAD). Rev Saude Publica 1995; 29(5): 359-363.

12. Botega NJ, Pondé MP, Medeiros P, Lima MG, Guerreiro CAM. Validation of the Hospital Anxiety and Depression Scale in ambulatory epileptic patients. J Bras Psiquiatr 1998; 47(6): 285-289.

13. Yusoff MS, Abdul Rahim AF, Baba AA, Ismail SB, Mat Pa MN, Esa AR. Prevalence and associated factors of stress, anxiety and depression among prospective medical students. Asian J Psychiatr 2013; 6(2): 128-33.

14. Yates J, James D, Aston I. Pre-existing mental health problems in medical students: a retrospective survey. Med Teach 2008; 30(3): 319-21.

15. Oliveira GS, Rocha CA, Santos BEF, Sena IS, Fávaro L, Guerreiro MC. Prevalence and factors associated with depression in medical students of the Federal University of Amapá. Rev Med Saude Brasilia 2016; 5(3): 186-99.

16. Hawkley LC, Cacioppo JT. Loneliness matters: a theoretical and empirical review of consequences and mechanisms. Ann Behav Med 2010; 40(2): 218-27

17. Eglit GML, Palmer BW, Martin AS, Tu X, Jeste DV. Loneliness in schizophrenia: construct clarification, measurement, and clinical relevance. Plos One 2018; 22(3): e0194021.

18. Stopa SR, Malta DC, Oliveira MM, Lopes CS, Menezes PR, Kinoshita RT. Prevalence of self-reported depression in Brazil: 2013 National Health Survey results. Rev Bras Epidemiol 2015; 18 (Suppl 2):170-180

19. Vasconcelos TC, Dias BRT, Andrade LR, Melo GF, Barbosa L, Souza E. Prevalence of anxiety and depression symptoms among medicine students. Rev Bras Educ Med [online] 2015; 39(1): 135-142.

20. Waqas A, Rehman A, Malik A, Muhammad U, Khan S, Mahmood N. Association of ego defense mechanisms with academic performance, anxiety and depression in medical students: a mixed methods study. Cureus [online] 2015; 7(9): e337
21. Ibrahim N, Al-Kharboush D, El-Khatib L, Al-Habib A, Asali D. Prevalence and predictor of anxiety and depression among female medical students in King Abdulaziz university, Jeddah, Saudi Arabia. Iran J Public Health 2013; 42(7): 726-36.

22. Quince TA, Wood DF, Parker RA, Benson J. Prevalence and persistence of depression among undergraduate medical students: a longitudinal study at one UK medical school. BMJ Open. 2012; 2(4): e001519. doi: 10.1136/bmjopen-2012-001519.

23. Lima MCP, Ramos-Cerqueira ATA, Dantas CL, Lamardo JR, Reis LEC, Torres AR. Hazing and the mental health of medical students. Rev Bras Educ Med 2018; 42(2): 99-120.

\section{AUTHORS' CONTRIBUTION}

Christiane Fernandes Ribeiro followed the entire process of development from conception to preparation of the manuscript. Carolina Martins Cabrita Lemos, Nina Nogueira Alt, Rulliany Lizia Tinoco Marins and Weydler Campos Hottz Corbiceiro have equally participated in the idealization, formulation and application of questionnaires, data analysis and writing the text. Maria Isabel do Nascimento assisted in the interpretation of data, as well as formatting the text and carried out the final revision. All of the authors approved the version submitted for publication.

\section{CONFLICTS OF INTEREST}

The authors declare that there is no conflict of interest regarding the publication of this article.

\section{ADDRESS FOR CORRESPONDENCE}

C.F. Ribeiro. Address: Rua Marquês do Paraná, no 303, Centro Niterói (RJ), Brasil.

CEP: 24.033-900. Departamento Materno-Infantil. $2^{\circ}$ andar. E-mail: chrisribeiro@vm.uff.br or chris_alvarenga@yahoo.com.br. Phone: +5521999171569 . 